\title{
EFFECT OF YTTRIUM AND ZIRCONIUM MICROALLOYING ON THE STRUCTURE AND PROPERTIES OF WELD JOINTS OF A TWO-PHASE TITANIUM ALLOY
}

\author{
UČINEK MIKROLEGIRANJA ITRIJA IN CIRKONIJA NA \\ STRUKTURO IN LASTNOSTI NA SPOJE ZAVROV DVOFAZNE \\ ZLITINE TITANA
}

\author{
Anatoly Illarionov, Artemy Popov, Svetlana Illarionova, Dmitry Gadeev \\ Ural Federal University, 620034, 28 Mira str., Yekaterinburg, Russia \\ d.v.gadeev@urfu.ru \\ Prejem rokopisa - received: 2016-11-10; sprejem za objavo - accepted for publication: 2017-04-19
}

doi: $10.17222 / \mathrm{mit} .2016 .317$

\begin{abstract}
The effect of microalloying of the Ti-4.8Al-1.2Mo-2.6V-0.6Cr-0.25Fe titanium alloy with yttrium and zirconium on the phase composition, structure and mechanical properties of welded sheets was studied using light and transmission electron microscopy, X-ray diffraction analysis and microindentation-hardness testing. A differential thermal analysis was employed to model the welding thermal cycle. It was found that alloying with yttrium led to the precipitation of $\mathrm{Y}_{2} \mathrm{O}_{3}$ oxide particles resulting in refining the microstructure of the alloy. In addition, yttrium additions were shown to stabilise the $\beta$-phase of the alloy that decreases the hardness of the alloy.

Keywords: microalloying, rare-earth elements, titanium alloy, welding

Učinek mikrolegiranja zlitine titana Ti-4.8Al-1.2Mo-2.6V-0.6Cr-0.25Fe z itrijem in cirkonijem na sestavo faze, strukturne in mehanske lastnosti je bil raziskovan s svetlobno elektronsko mikroskopijo, z rentgensko difrakcijsko analizo in s testiranjem trdote mikroindentacije. Uporabili smo diferencialno termično analizo za pridobitev modela za varilni termični cikel. Ugotovljeno je bilo, da legiranje $\mathrm{z}$ itrijem vodi k razpršenosti $\mathrm{Y}_{2} \mathrm{O}_{3}$ oksidnih delcev, kar se kaže pri rafiniranju mikrostrukture zlitine. Poleg tega je bilo dokazano, da so dodatki itrija stabilizirali $\beta$-fazo v zlitini, ki zmanjšuje trdoto zlitine.

Ključne besede: mikrolegiranje, elementi redke zemlje, zlitina titana, varjenje
\end{abstract}

\section{INTRODUCTION}

Titanium alloys, due to their high specific strength and good corrosion resistance, are widely used in the aerospace and marine industries as structural materials and it is desirable to further enhance their properties. The latter is possible by means of complex multicomponent alloying. ${ }^{1,2}$ In addition to the specific strength, good weldability is usually necessary to maximise the material utilisation.

Since $\alpha$-titanium and $\alpha+\beta$ alloys are considered to have a better weldability compared to metastable $\beta$-titanium alloys, ${ }^{3}$ a number of $\alpha+\beta$-alloys were developed in Russia to meet these requirements. One of them is Ti-4.8Al-1.2Mo-2.6V-0.6Cr-0.25Fe, which is a typical martensite-type two-phase alloy. ${ }^{4}$

Despite good weldability, the welding usually negatively affects the mechanical properties of titanium alloys. ${ }^{5}$ This is partly due to the oxygen absorbed from the shield atmosphere followed by its diffusion to the weld-fusion zone (FZ), partly due to a high heat input resulting in significant grain coarsening. One way to overcome such a problem is to refine the prior grain size by the grain-boundary pinning effect of second-phase particles and promote heterogeneous nucleation in the
FZ. ${ }^{6}$ It was shown that microalloying with transition elements, especially rare-earth metals, is a promising way to refine the structure of titanium alloys. ${ }^{7}$ One of the most frequently employed alloying elements is yttrium. ${ }^{8-11}$

Although it was already shown what microalloying of the Ti-4.8Al-1.2Mo-2.6V-0.6Cr-0.25Fe alloy with $0.06 \%$ mass fraction of yttrium decreases the oxygen concentration in $\alpha$ - and $\beta$-solid solutions due to the formation of $\mathrm{Y}_{2} \mathrm{O}_{3}$ particles, ${ }^{4}$ detailed studies of a weld structure were not conducted. This is why our study aimed at investigating the influence of microalloying titanium alloys with zirconium and yttrium on the microstructure formation and mechanical properties of the weld joints of this alloy.

\section{EXPERIMENTAL PART}

Two-millimeter-thick hot-rolled sheets of an $(\alpha+\beta)$ martensitic titanium alloy alloyed with yttrium (alloy 1) and zirconium (alloy 2) were used in this study. The chemical compositions of the alloys are shown in Table 1. Prior to their use, the sheets were subjected to vacuum annealing at $750{ }^{\circ} \mathrm{C}$ for $1 \mathrm{~h}$ followed by arc welding using non-consumable tungsten electrodes. 
A. G. ILLARIONOV et al.: EFFECT OF YTTRIUM AND ZIRCONIUM MICROALLOYING ON THE STRUCTURE ...

Table 1: Chemical compositions of the test materials, in mass fractions $(w / \%)$

\begin{tabular}{|c|c|c|c|c|c|c|c|c|}
\hline \multirow{2}{*}{ Materials } & \multicolumn{6}{|c|}{ Alloying elements, in mass fractions $(w / \%)$} \\
\cline { 2 - 9 } & $\mathrm{Ti}$ & $\mathrm{Al}$ & $\mathrm{Mo}$ & $\mathrm{V}$ & $\mathrm{Cr}$ & $\mathrm{Fe}$ & $\mathrm{Y}$ & $\mathrm{Zr}$ \\
\hline Alloy 1 & $\mathrm{Bal}$ & 4.80 & 1.20 & 2.60 & 0.60 & 0.60 & 0.06 & - \\
\hline Alloy 2 & & & & & & & - & 0.07 \\
\hline
\end{tabular}

The microstructures of the alloys were analyzed with light optical (LOM) and transmission electron (TEM) microscopy on Olympus GX51 and JEM 200C microscopes, respectively. A qualitative phase analysis was carried out using X-ray diffraction (XRD) with $\mathrm{Cu}-K_{\alpha}$ radiation on a DRON-3M powder diffractometer. A differential thermal analysis (DTA) was performed on a Du Pont appliance in DTA-1600 crucibles. The average grain size and grain-size distribution were determined with an Epiquant optical microscope.

Vickers microhardness was measured at a $1 \mathrm{~N}$ load in accordance with the formula below (ISO 6507) and multiplied with the standard gravity $(\mathrm{g}=9.81)$ to get the values in $\mathrm{MPa}$ in Equation (1):

$$
\mathrm{HV}=0.1891 \cdot\left(F / d^{2}\right)
$$

with $F$ being the applied load (Newton) and $d$ being the average length of the diagonal of the residual indent (millimeters).

Metallographic samples were prepared according to the standard procedures. The steps consisted of grinding with 120-2400 grit SiC paper, polishing with $0.3 \mu \mathrm{m}$ colloidal alumina, followed by the final polishing with a $0.05 \mu \mathrm{m}$ colloidal silica suspension. Kroll' s reagent with a composition of $100 \mathrm{~mL}$ water $+2 \mathrm{~mL} \mathrm{HF}+5 \mathrm{~mL}$ $\mathrm{HNO}_{3}$ was used to etch the specimens. ${ }^{12}$ Thin foils for the TEM investigation were prepared with electrolytic polishing in a methanol-containing electrolyte $(300 \mathrm{~mL}$ methanol, $175 \mathrm{~mL}$ butanol, $30 \mathrm{~mL}$ perchloric acid $(70-72 \%)$ ) at $-30{ }^{\circ} \mathrm{C} .{ }^{12}$

\section{RESULTS AND DISCUSSION}

With respect to the differences in the microstructure, weld joints generally consist of three distinct zones, i.e., the base metal, the fusion zone and the heat-affected zone. In the fusion zone (FZ), materials melt during the welding and crystallize during the subsequent cooling. The heat-affected zone (HAZ) corresponds to the narrow transition region between the base metal and the fusion zone where the material is heated up to sub-transus or even superheated above the critical temperature. The latter might obviously cause significant microstructure changes in comparison with the base metal.

On the present samples, the zone width was measured and it was around $12 \mathrm{~mm}$ and $4.5 \mathrm{~mm}$ for the fusion and heat-affected zones, respectively (Figure 1).

The base-metal microstructure of both alloys is represented by primary $\alpha$-phase precipitates of a mixed, globular and lamellar, morphology in a $\beta$-phase matrix

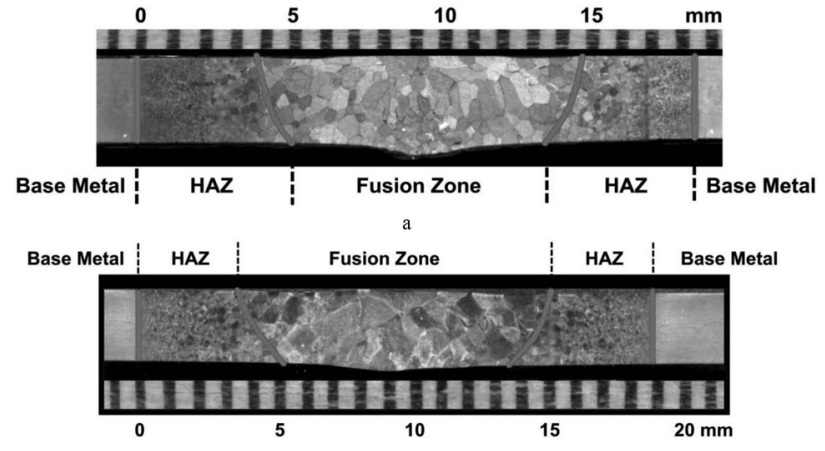

Figure 1: Structures of welded joints: a) alloy 1 with $Y$; b) alloy 2 with $\mathrm{Zr}$

(Figure 2a). The yttrium-containing alloy 1 is distinguished by a dispersive oxide precipitation of $\mathrm{Y}_{2} \mathrm{O}_{3}$ particles with the average diameter of up to $120 \mathrm{~nm}$ (Figure 2b). These particles were found to be almost spherical and to precipitate mainly near the grain boundaries. The TEM micrograph (Figure 2b) shows a specific 'comet-tail-like' contrast around these particles, which is attributed to the elastic-stress field caused by the difference between the thermal-expansion coefficients of the oxides and the matrix.

The average $\beta$-phase grain size decreased with the increasing distance from the FZ (Figure 1) due to the higher temperatures achieved in the HAZ close to the

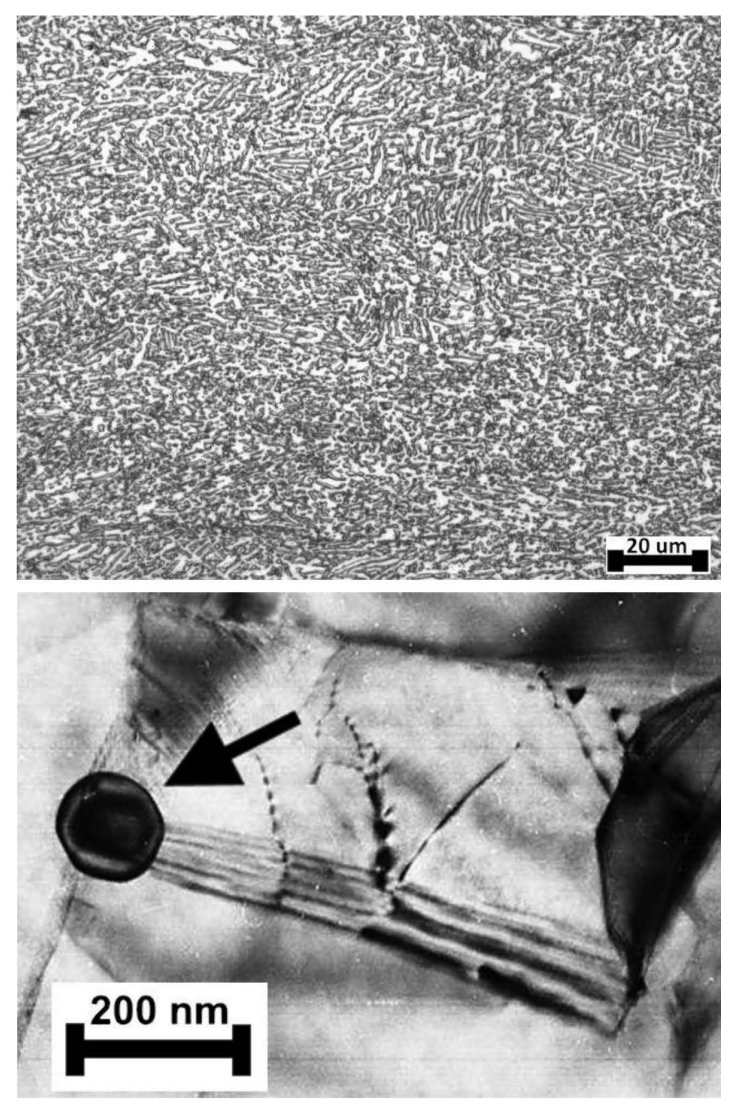

Figure 2: Microstructures of base metals: a) alloy 2 (LOM); b) alloy 1 (TEM) 
FZ. The coarsest grains of alloy 2 reached about $400 \mu \mathrm{m}$ in diameter, whereas in alloy 1 , they did not exceed 330 $\mu \mathrm{m}$, i.e., the yttrium-containing alloy 1 was characterized by a 1.2 times finer grain size. A similar relationship was previously observed in the solution-treated and waterquenched alloys of the same composition ${ }^{4}$ and it was attributed to the presence of the yttrium-oxide particles in the Y-containing alloy that inhibited the grain-boundary movement.

The X-ray diffraction analysis showed that the volume fractions of the $\alpha$ - and $\beta$-phases varied significantly in different parts of the HAZ (Figure 3). The intensity of $\beta$-phase peaks in the XRD patterns decreased with the increasing distance from the FZ, clearly indicating that the volume fraction of the $\beta$-phase was significantly higher in the near-FZ areas. At the same time, the $\mathrm{a}_{\beta}$ lattice parameter changed in the opposite direction.

It can be seen that the $(200)_{\beta}$-peak intensity ratio for alloy 1 was considerably higher than that for alloy 2 . This confirms the assumption that yttrium binds oxygen, thus increasing the stability of the supercooled $\beta$-phase upon cooling..$^{4,8-9}$ Furthermore, such a behaviour resulted in a higher $\beta$-phase volume fraction, decreasing the hardness of the alloy. This was confirmed with the microhardness-indentation tests. Alloy 1 had a lower microhardness $(2800 \pm 50 \mathrm{MPa})$ than alloy $2(3300 \pm 50 \mathrm{MPa})$. It was also found that the $\alpha$-phase morphology along the HAZ changed from a complex one (Figure 2) to a lamellar one consisting of thin platelets (Figure 4).

The analysis of the microstructures of the alloys revealed a noticeable feature of both alloys, i.e., a jagged shape of the grain boundaries. A similar phenomenon was seen previously, for instance, in $\mathrm{Ni}-\mathrm{Mn}$-In-based alloys after thermal cycling ${ }^{13}$ and near-alpha titanium alloys ${ }^{14}$ and it was attributed to the formation of martensite crystals, which grow towards the grain boundaries curving them. Figure 4a shows that such a shape coincides closely with the lamellar $\alpha$-phase precipitations on both sides of the grain boundaries. Thin $\alpha$-lamellae were formed during the cooling from the single-phase

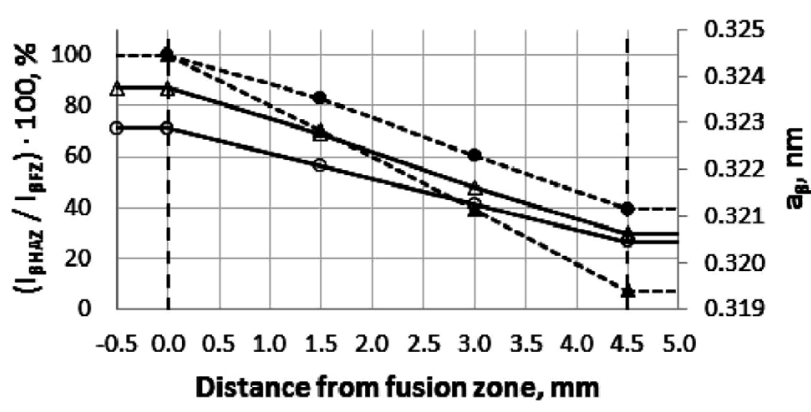

$$
\begin{gathered}
\Delta, \triangle-\text { alloy } 1 ; \bullet, 0-\text { alloy } 2 \\
I_{H A Z} I_{F Z}-(200)_{\beta} X R D \text { peak intensity in the heat-affected and fusion zones }
\end{gathered}
$$

Figure 3: $\beta$-phase lattice parameter $\left(a_{\beta}\right)$ and $(200)_{\beta}$ XRD-peak intensity ratio $\left(I_{\beta \mathrm{HAZ}} / I_{\beta \mathrm{FZ}}\right)$ as a function of distance from the fusion zone of a welded joint

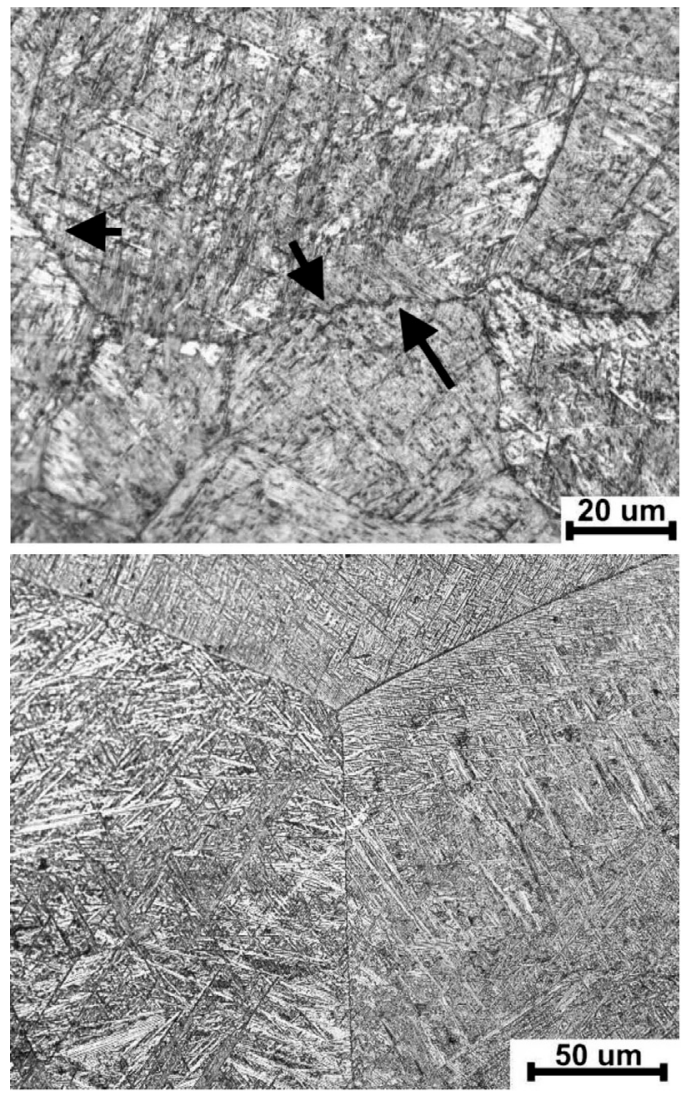

Figure 4: Microstructures of heat-affected zones of weld joints: a) alloy 1, b) alloy 2

$\beta$-region. The stress field next to the growing $\alpha$-lamellae could interact with the grain boundaries curving them. The same process occurred in the neighbouring grains resulting in the jag formation. Since this process can occur in preferentially oriented grains, the jags were found only on the corresponding parts of the grains. On the whole, we suppose that the jagged shape of the grain boundaries is associated with the interaction of the boundaries with the products of the $\beta \rightarrow \alpha$-transformation occurring upon the cooling.

To summarize the above, it can be concluded that the welding thermal cycle results in significant changes of the grain structure, phase composition and morphology of the phases. Yttrium binds oxygen forming oxide particles that inhibit the grain growth and improve the $\beta$-phase stability. In turn, microalloying the alloy with zirconium does not result in the formation of additional phases and leads to the solution hardening of the alloy.

The average grain sizes for the weld joints of the samples of alloys 1 and 2 did not show any significant difference and was about 480-600 $\mu \mathrm{m}$ (Figure 1). The fine structure of the alloys mainly consists of the $\alpha$-phase, with dislocations perpendicular to the lamellae (Figure 5b).

The $\alpha$-lamellae in the FZs of the alloys tend to form small colonies that may cross differently oriented lamellae (Figure 5c). Interlamellar $\alpha / \beta$ spacings in 
A. G. ILLARIONOV et al.: EFFECT OF YTTRIUM AND ZIRCONIUM MICROALLOYING ON THE STRUCTURE ...
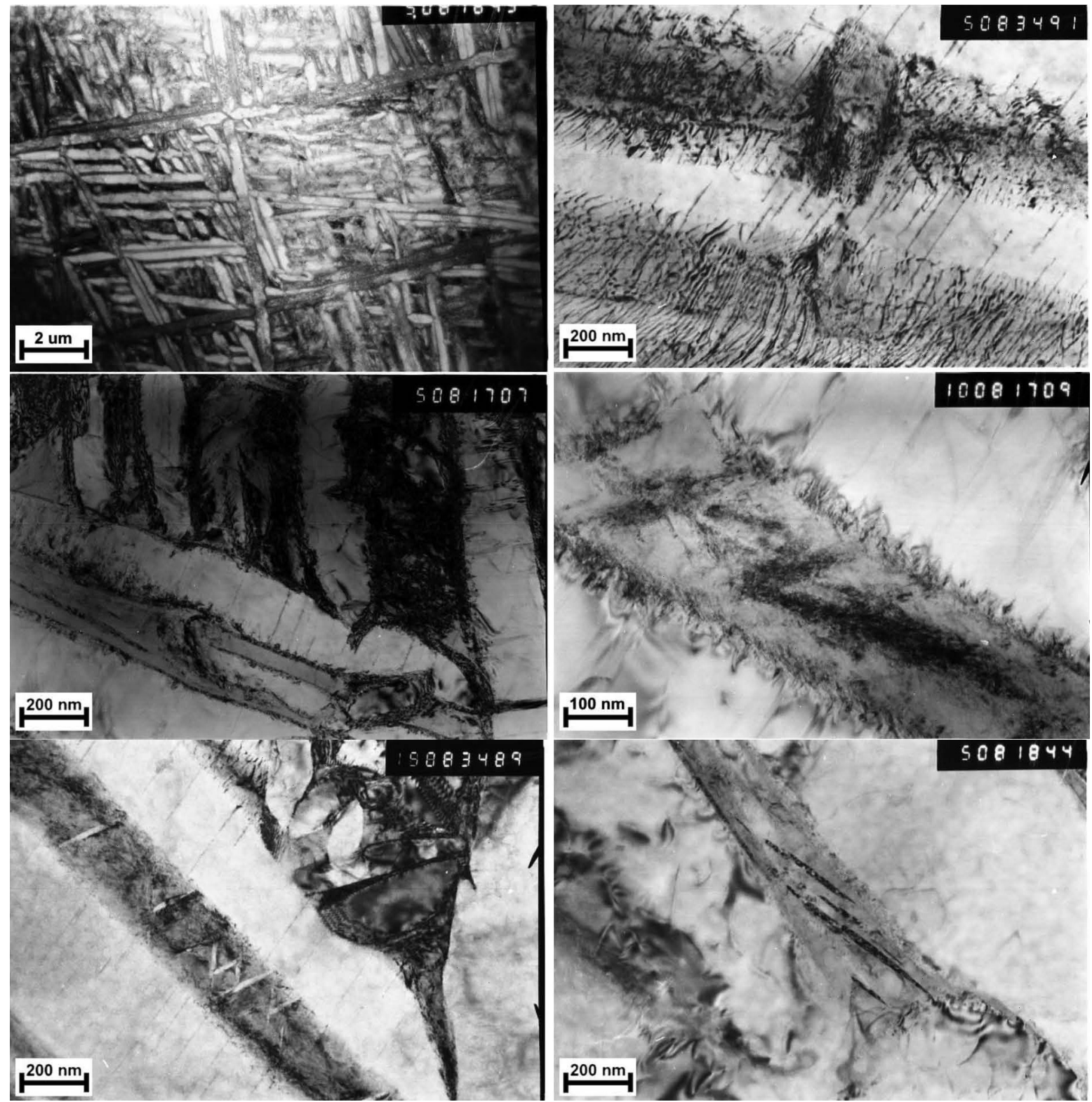

Figure 5: Thin structures of the weld joints of alloys 1 and 2: a), c), d) alloy 1; b), e), f) alloy 2

alloy 2 have a complex structure and high dislocation density (Figure 5d). $\beta$-phase interlayers are relatively wide (up to $200 \mathrm{~nm}$ ) and non-uniform throughout the bulk of the alloy. Secondary $\alpha$-phase precipitations were observed in the interlamellar spacings, both along and across the $\beta$ interlayers as well as at the $\alpha / \beta$-interphase boundaries (Figure 5d).

Generally, the coarse $\alpha$-platelets with a small dislocation density prevail in both yttrium- and zirconiumcontaining alloys (Figures 5e, 5f). However, alloy 1 is distinguished by a more conventional structure of interlamellar spacing. Although the thin lenticular platelets of the secondary $\alpha$-phase were still present, no highly dispersive precipitates were found on the interphase boundaries and within the $\beta$-layers. It should be noted that no $\mathrm{Y}_{2} \mathrm{O}_{3}$ particles were detected in the FZ. This might be connected with the intense overheating of the alloy caused by welding that resulted in a dissociation of the oxide.

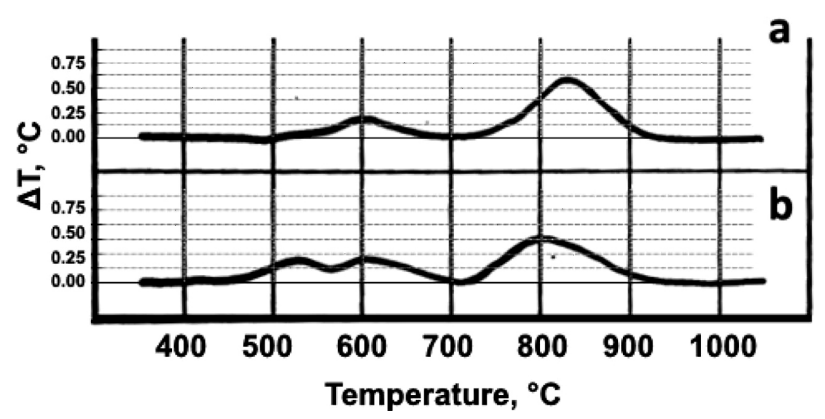

Figure 6: DTA curves for continuous cooling $\left(20^{\circ} \mathrm{C} / \mathrm{min}\right.$ cooling rate) from $1200{ }^{\circ} \mathrm{C}$ : a) alloy 1, b) alloy 2 
In order to model the welding thermal cycle, a number of DTA experiments involving continuous heating up to $1200{ }^{\circ} \mathrm{C}$ and the subsequent cooling to $20{ }^{\circ} \mathrm{C} / \mathrm{min}$ were carried out. Continuous-cooling DTA curves allowed us to determine the temperature ranges of the $\beta \rightarrow \alpha$-transformation (Figure 6).

A comparative analysis of the curves showed that the $\beta$-phase decomposition process in alloy 2 consisted of three distinctive stages, whereas only two exothermal effects were found for alloy 1. Stages I and II (at 920-750 and $700-550{ }^{\circ} \mathrm{C}$, respectively) were attributed to the formation of coarse primary $\alpha$-colonies with a low defect density and secondary $\alpha$-platelets within the $\beta$-matrix. Stage III $\left(500-400{ }^{\circ} \mathrm{C}\right)$ was assigned to the precipitation of the highly dispersed $\alpha$-precipitates mentioned above (Figure $5 \mathbf{d}$ ).

The formation of the $\alpha$-phase upon supercooling below the transus temperature of the titanium alloys is initiated by the crystallographic defects of the structure such as grain boundaries, dislocations, etc. Yttrium binds oxygen and thus refines the alloy. The products of the $\beta$-phase decomposition were quite free of precipitates. On the other hand, the precipitation of the secondary $\alpha$-platelets was possible in both alloys studied during supercooling of up to about $600{ }^{\circ} \mathrm{C}$. At lower temperatures, the $\beta$-phase was stabilized in alloy 1 , whereas its further decomposition occurred in alloy 2 resulting in the formation of highly dispersed $\alpha$-precipitates. We believe that all these differences in the behaviour of the alloys are associated with different $\beta$-phase stability values, which are primarily defined by the concentration of impurities in the alloys. Specifically, the interstitial elements in alloy 1, mainly oxygen, are bound to yttrium in the form of oxides. Zirconium has a lower affinity for oxygen and thus oxygen atoms remain in the solid solution leading to a more complete $\beta$-phase decomposition upon the cooling (Figure 2) resulting in a lower $\beta$-phase lattice parameter. With an increase in the volume fraction of the body-centred cubic $\beta$-phase, the strength of the titanium alloys usually decreases. ${ }^{12}$ This is why the microhardness of Y-containing alloy 1 was found to be lower (3300 $\pm 100 \mathrm{MPa}$ for alloy 2) and $3000 \pm 100 \mathrm{MPa}$ for alloy 1$)$.

\section{CONCLUSIONS}

The influence of the microalloying of titanium alloy Ti-4.8A1-1.2Mo-2.6V-0.6Cr-0.25Fe with yttrium and zirconium on the structure and microhardness was considered. It was found that the alloying with yttrium has the most noticeable effect on the structure of a weld joint and the phase transformation of the alloy.

A yttrium addition refines the alloy by means of binding with oxygen atoms and forming $\mathrm{Y}_{2} \mathrm{O}_{3}$ particles. These particles pin the grain boundaries in both the heat-affected and fusion zones, inhibiting the grain growth during a welding thermal cycle. In addition, due to a lower concentration of oxygen in the $\alpha$-phase, yttrium decreases the $\beta$-transus temperature of the alloy leading to the stabilization of the supercooled $\beta$-phase.

Due to a higher volume fraction of the "soft" $\beta$-phase in the yttrium-containing alloy, its microhardness was shown to be lower than that of the alloy with zirconium.

\section{Acknowledgment}

We hereby acknowledge the support of the Ministry of Science and Education of the Russian Federation, in accordance with the decree of the Government of 9 April 2010, No. 218, project No. 03.G25.31.0234.

\section{REFERENCES}

${ }^{1}$ A I. Khorev, Development of structural titanium alloys for components and sections in aerospace technology, 10 (2010), 13-23, doi:10.1080/09507116.2010.486188

${ }^{2}$ A. I. Khorev, Complex alloying and heat treatment of titanium alloys, 6 (2008), 364-368, doi:10.1080/09507110802288312

${ }^{3}$ M. J. Donachie, Titanium, A Technical Guide, $2^{\text {nd }}$ ed., ASM International, 2000

${ }^{4}$ A. G. Illarionov, A. A. Popov, S. M. Illarionova, Effect of Microalloying, with Rem Inclusively, on the Structure, Phase Composition and Properties of $(\alpha+\beta)$-Titanium Alloy, Metal Science and Heat Treatment, 57 (2016), 719-725, doi:10.1007/s11041-016-9948-0

${ }^{5}$ E. W. Collings, The physical metallurgy of titanium alloys, American Society for Metals, 1984, 261

${ }^{6}$ Rios PR. Overview No. 62: A theory for grain boundary pinning by particles, Acta Metall., 35 (1987) 12, 2805-2814

${ }^{7}$ A. I. Khorev, Theory and practices of microalloying of near- $\alpha$ and $\alpha+\beta$ titanium alloys with REE, zirconium, hafnium and rhenium, Techologii machinostroeniya, 1 (2015), 5-10

${ }^{8}$ H. Wu, Y. Han, X. Chen, Effects of Yttrium on Mechanical Properties and Microstructures of Ti-Si Eutectic Alloy, Chinese Journal of Aeronautics, 18 (2005), 171-174, doi:10.1016/S1000-9361(11) 60324-5

${ }^{9}$ R. P. Kolli, A. A. Herzing, S. Ankem, Characterization of yttriumrich precipitates in a titanium alloy weld, Materials Characterization, 122 (2016), 30-35, doi:10.1016/j.matchar.2016.10.014

${ }^{10}$ B. Poorganji, A. Kazahari, T. Narushima, C. Ouchi, T. Furuhara, Effect of yttrium addition on grain growth of $\alpha, \beta$ and $\alpha+\beta$ titanium alloys, Journal of Physics: Conference Series, 240 (2010), 12170 , doi:10.1088/1742-6596/240/1/012170

${ }^{11}$ W. F. Cui, C. M. Liu, L. Zhou, G. Z. Luo, Characteristics of microstructures and second-phase particles in Y-bearing Ti-1100 alloy, Materials Science and Engineering: A, 323 (2002), 192-197, doi:10.1016/S0921-5093(01)01362-4

${ }^{12}$ G. Lütjering, J. C. Williams, Titanium, $2^{\text {nd }}$ ed., Springer, Berlin, 2007, 442

${ }^{13}$ Y. V. Kaletina, E. D. Efimova, E. G. Gerasimov, A. Y. Kaletin, Effect of thermal cycling on structure and properties of Ni-Mn-In-based alloys, Technical Physics, 12 (2016), 1894-1897

${ }^{14}$ H. M. Flower, P. R. Swann, D. R. F. West, The effect of Si, Zr, Al and Mo on the structure and strength of Ti martensite, Journal of Materials Science, 8 (1972), 929-938 